\title{
Menabur Kebiasaan: Propaganda Gerakan Menabung Jepang (1941-1945)
}

\author{
Mufidha Brilian Irianti
}

Mahasiswa pascasarjana Universitas Gadjah Mada, Yogyakarta.

\begin{abstract}
Abstrak
Japan colonialism during World War II brought significant impact for Indonesia. Aside from political and social impacts, it has affected daily life. Japanese occupation was meant to recruit human resources from the region on behalf of the Pacific War. Japan made efforts to capture the attention and cooperation of locals. Japanese propaganda used a variety of media to send the messages. One such propaganda consisted to persuade people to save in formal institutions. In order to reach people of all backgrounds, military government used a variety of mass media such as newspapers, magazines, movies, and radio as well as a kind of theatrical art and singing. The concern of the paper is to describe the strategies of Japanese savings propaganda. Exploring how government used media to persuade people to make saving accounts in modern financial institution.
\end{abstract}

Kata kunci: Money saving, Japanese period, Propaganda, Indonesia

\section{Pendahuluan}

Keterlibatan Jepang dalam Perang Dunia II yang membawanya menduduki Indonesia banyak dikenang sebagai kurun waktu yang cukup signifikan dalam perjalanan kehidupan bangsa. Tujuan penguasaan Jepang atas Indonesia didasari oleh keinginannya untuk membangun kemakmuran bersama Asia Timur Raya ${ }^{1}$ demi menandingi aliansi negaranegara Barat.

Rangkaian kegiatan Jepang untuk mewujudkan cita-cita membangun lingkungan kemakmuran bersama Asia Timur Raya tersebut, diawali dengan menciptakan sebuah masyarakat yang memiliki visi, misi sama dan masyarakat yang bersedia sepenuhnya

1 Daitōa Kyoiken (Persemakmuran Asia Timur Raya) merupakan ide Jepang dalam menciptakan lingkungan bersama kemakmuran (persatuan ekonomi dan pertahanan bersama) di wilayah Asia Timur Raya. Ide tersebut berakar dari semboyan Jepang yang lain yaitu hokko ichiyu (menguasai dunia di bawah satu atap Jepang). bekerjasama. Tujuannya adalah supaya Jepang bisa dengan mudah memobilisasi seluruh rakyat untuk berpartisipasi dalam program-program yang dicanangkannya. Hal demikian diwujudkan Jepang dengan cara mengindoktrinasi masyarakat demi merubah pikiran dan tingkah laku mereka sehingga bisa dijadikan mitra yang dapat dipercaya dalam lingkungan Kemakmuran Bersama Asia Timur Raya. Jepang berfikir untuk membentuk orang Indonesia sepenuhnya ke dalam pola tingkah laku dan cara berfikir Jepang, sehingga sebagai salah satu elemen pendukung perang, orang Indonesia bersedia berpartisipasi dalam program-program mereka dalam mewujudkan misinya (Kurosawa, 1993: 229). Dalam rangka menjalankan semua itu, propaganda dipilih sebagai jalan yang sangat penting sebagai mesin perang Jepang.

Propaganda sendiri menurut Lindley Fraser merupakan kegiatan atau seni untuk mengajak orang lain bertingkah-laku sesuai 
dengan apa yang dikehendaki dan tidak bertingkah-laku seperti yang tidak diinginkan (Sunarjo, 1982: 27). Sedangkan menurut Leonard W. Doob (1948), propaganda didefinisikan sebagai usaha untuk mempengaruhi kharakter dan untuk mengendalikan tingkah laku orang lain di dalam sebuah masyarakat pada waktu tertentu (Jowett \& O’Donell, 2012: 4). Propaganda sebagai bagian dari manajemen negara serta merupakan hasil dari hubungan pemerintah dengan rakyatnya, menjadi sangat penting dilancarkan terutama pada masa perang.

Tujuan utama propaganda Jepang baik sebelum maupun ketika perang berlangsung adalah untuk membawa rakyat Jepang dan rakyat Asia berpartisipasi secara aktif menuju garda depan bersama dengan pemerintah militer Jepang. Propaganda tersebut meliputi berbagai hal, mulai dari propaganda untuk bergabung sebagai tentara hingga propaganda yang berhubungan dengan kebiasaan seharihari masyarakat termasuk seruan untuk berhemat dan menabung. Berdasarkan beberapa sumber yang penulis temukan, seruan untuk berhemat dan menabung dilancarkan sebagai bagian dari strategi propaganda perang Jepang selama pendudukannya di Indonesia.

Tidak hanya berkaitan dengan bagaimana menghemat dan menabungkan uang, pada dasarnya, ajakan secara umum untuk melakukan penghematan berkaitan dengan gaya hidup selama perang telah disosialisasikan oleh pihak Jepang.Sosialisasi yang intensif tentang anjuran untuk berhemat dan menabung guna mendukung kepentingan perang salah satunya dapat kita lihat pada peryataan yang terdapat dalam majalah Djawa Baroe seperti berikut,

"Goena mentjapai kemenangan terachir dalam peperangan Asia Timoer Raya sedapatdapatnja hendaklah kita menghematkan belandja kehidoepan sehari-hari, Sebaliknja haroeslah kita giat bekerdja dan radjin menaboeng oeang” (Djawa Baroe, Edisi 5, 15 Juni 1943)

\section{Media Massa Sebagai Awal Segalanya}

Dalam melancarkan propaganda menabung, Jepang memanfaatkan berbagai media yang saat itu berkembang pesat. Seperti yang diungkapkan Barak Kushner dalam The Thought War, Japanese Imperial Propaganda propaganda Jepang pada masa perang bergantung pada jalannya konsumsi terhadap media massa yang telah berkembang selama era demokrasi Taisho pada dekade 1920-an. Mulai dari media cetak seperti koran, majalah dan poster, hingga media elektronik seperti seruan di radio dan pembuatan video atau film pendek. Berikut ini adalah uraian mengenai media tersebut.

\section{Koran}

Propaganda menabung yang disebarkan melalui surat kabar antara lain terdapat dalam harian Asia Raya yang terbit di Jakarta, harian Tjahaya yang terbit di Bandung, Soeara Asia yang terbit di Surabaya dan Sinar Matahari yang terbit di Yogyakarta. Berbagai artikel dalam bentuk seruan, berita dan bahkan cerita pendek diproduksi untuk menggiring masyarakat agar menyisihkan uang yang mereka miliki dan mau mempercayakannya kepada lembaga-lembaga keuangan. Beberapa berita dalam surat kabar tersebut antara lain memuat informasi tentang pembukaan perkumpulan-perkumpulan menabung di berbagai daerah dari kota sampai desa dan memuat juga berita tentang kegiatan-kegiatan menabung yang dilakukan oleh murid-murid, pegawai, tentara, bahkan sampai kumpulan pedagang beras.

Penulis menemukan berbagai artikel berkenaan dengan tabungan dalam koran Asia Raya yang terbit sekitar tahun 1942 hingga 1945. Diantaranya adalah pemberitaan 
mengenai 400 orang dari Barisan Pemuda Asia Jakarta yang setiap harinya mengumpulkan uang dan seminggu sekali uang yang dikumpulkan tersebut disetorkan ke kantor pos. Kemudian berita tentang murid-murid, perkumpulan pedagang kapas serta para pejabat daerah yang rajin menabung

Selain Asia Raya, surat kabar lain seperti Soeara Asia juga memuat artikel yang berkenaan dengan penabungan. Di antaranya adalah sebuah artikel yang menganjurkan untuk membentuk perkumpulan-perkumpulan menabung. Di dalam artikel tersebut dicantumkan syarat-syarat dan ketentuan apabila hendak membuat sebuah perkumpulan menabung serta peraturan-peraturan pelaksanaannya. Secara rinci dari poin pertama hingga poin ke dua belas dijabarkan dalam artikel tersebut mengenai tata cara pembuatan perkumpulan menabung (Soeara Asia, 1943).

Harian Tjahaya juga beberapa kali mengangkat tema tentang penabungan dalam terbitannya. Salah satunya adalah liputan tentang aktivitas menabung di kalangan petani. Diberitakan bahwa para petani, berkat anjuran dari Jawatan Pertanian telah membentuk suatu himpunan penabungan guna mewadahi semangat menabung demi usaha mencukupi kebutuhan mereka di masa mendatang (Tjahaya, 1943: 2).

Selain berupa berita, iklan maupun cerpen, dalam surat kabar dimuat pula tentang iklan undian nasabah tabungan pos, tata cara mengikuti undian serta pengumuman pemenang undian. Selain itu, melalui koran pula dilaporkan tentang jumlah uang tabungan yang terkumpul dari masyarakat setiap periode tertentu. Laporan semacam ini dimaksudkan untuk memberikan gambaran bahwa semakin hari masyarakat semakin gemar menabung dan diharapkan target untuk mencapai jumlah nominal tertentu dapat diwujudkan dengan semangat menabung yang semakin besar.

\section{Majalah}

Meskipun tidak terbit setiap hari, majalah memiliki keunggulan tersendiri sebagai media cetak yang bisa menampilkan gambar lebih detail dan kolom dengan narasi yang lebih panjang. Sehingga, pemanfaatan majalah sebagai bagian dari strategi propaganda menabung Jepang tidak kalah menariknya dengan koran.

Pertama, penulis mendapatkan sebuah artikel dengan judul "Nasehat Jang Bermanfa'at" pada edisi Djawa Baroe Juli 1944. Artikel ini berupa sebuah cerita pendek dengan karikatur yang menceritakan seorang Jawa bernama Sastrowikromo yang baru saja menerima upah dan diberi nasihat oleh pimpinannya. Nasihat itu berbunyi,

"Ingat, kang Sastro oeang ini djangan dibelikan barang jang tidak sangat perloe. Ingat, sekarang kita dalam peperangan jang hebat; hidoep sederhana dan hemat haroes mendjadi tjara hidoep kita. Ingat djoega, djalan dari kantor ini sampai roemahmoe djaoeh sekali, dan moengkin ada orang pendjahat merampas oeangmoe. Maka dari itoe djanganlah ragoe-ragoe, pergilah teroes kekantor pos, simpanlah oeangmoe disana. Djikalau kamoe memerloekan oeang, sewaktoewaktoe bisa diambil kembali." (Djawa Baroe, Juli 1944, hal.33-34)

Diceritakan bahwa Sastro kemudian melakukan segala apa yang dinasihatkan oleh pimpinannya tersebut. Dia pergi ke kantor pos untuk menyimpan uangnya dan memperoleh sebuah buku tabungan. Ketika perjalanan pulang, dia dihadang oleh sekawanan penjahat yang meminta uang darinya. Sastro mengatakan pada kawanan penjahat tersebut bahwa semua uangnya telah disimpan di kantor pos dan di tangannya sekarang hanya tersisa sebuah buku tabungan. Sang penjahat kemudian merampas buku tersebut dan pergi ke kantor pos dengan berpura-pura sebagai Sastro. Sesampai di kantor pos, penjahat tersebut kebingungan 
ketika harus diminta tanda tangan. Seketika petugas langsung mencurigai gelagatnya dan melaporkan hal tersebut kepada pimpinan kantor pos. Akhir cerita, penjahat tersebut kemudian diringkus dan buku tabungan Sastro berhasil diamankan dan dikembalikan padanya. Pesan terakhir dari cerita yang disertai gambar karikatur ini adalah Sastro kemudian percaya penuh bahwa seamanamannya menabung, adalah di kantor pos. Dari artikel ini, kita bisa melihat bagaimana Jepang berusaha mensosialisasikan agar masyarakat berbondong-bondong menabung di lembaga keuangan daripada menyimpan uang di rumah.

Selain cerita pendek tersebut, Djawa Baroe pada periode Agustus 1944 juga memuat berita yang disertai foto-foto tentang gerakan menabung tonarigumi. Foto-foto yang ditampilkan tersebut diantaranya adalah foto pawai atau arak-arakan memperingati telah terkumpulnya uang tabungan pos sejumlah sepuluh juta rupiah. Kemudian gambar berikutnya adalah foto sekumpulan warga yang menyetorkan uang tabungan mereka kepada petugas di rumah Kumicho (ketua tonarigumi) dengan membawa buku tabungan. Dinarasikan di kolom tersebut bahwa kegiatan serupa dilakukan setiap minggu di tiap-tiap tonarigumi. Gambar selanjutnya adalah gambar Kumicho dan petugas tabungan (Chokin-Hanchou) yang telah ditunjuk di setiap tonarigumi melakukan pekerjaan menerima dan mencatat tabungan dari para warga. Selanjutnya adalah foto aktivitas chokinghanchou menyetorkan seluruh tabungan warga ke chokin-kyoku.

\section{Video atau Film}

Selain koran dan majalah, Jepang juga memanfaatkan media lain untuk menyebarkan propagandanya, termasuk dalam hal seruan untuk menabung. Para ahli propaganda Jepang sadar bahwa tingkat pendidikan masyarakat Jawa masih sangat rendah dan masih banyak yang buta huruf. Maka, salah satu yang menjadi ciri skema propaganda Jepang adalah digunakannya secara efektif media audiovisual seperti film dan siaran radio yang sangat efektif menjangkau rakyat pedesaan yang buta huruf (Kurosawa, 1993: xix).

Aiko Kurosawa menyatakan bahwa salah satu media propaganda masa perang yang paling penting adalah film. Sejak awal pendudukan, pemerintah telah berupaya untuk menguasai sepenuhnya kendali dunia perfilman dan dijadikan sebagai alat propaganda perang yang signifikan. Sehingga pada bulan Oktober 1942, dibentuklah sebuah organisasi sementara untuk menjalankan kebijakan perfilman (Jawa Eiga $K o \bar{s} h a^{2}$ ) setelah sebelumnya tentara ke16 Angkatan Darat Jepang menyita seluruh perusahaan film begitu berhasil menguasai pulau Jawa.Namun, tidak berapa lama setelah itu, kendali dunia perfilman dialihkan pada dua perusahaan Jepang Nichi'ei dan Eihai yang keduannya berkator pusat di Tokyo.Sejak saat itu, industri perfilman disatukan ke dalam jaringan besar yang membentang di seluruh wilayah Lingkungan Kemakmuran Bersama Asia Timur Raya (Kurosawa, 1993: 237-238).

Sehingga, tidak mengherankan jika sekarang bisa ditemukan puluhan film atau video produksi pemerintah pendudukan Jepang yang berhubungan dengan upaya propaganda tersebut. Menurut Aiko Kurosawa, prioritas tertinggi industri film pada masa itu ada pada film dokumenter, kebudayaan dan film berita. Salah satu kategori film yang diproduksi tersebut adalah yang menekankan pada peningkatan produksi dan kampanye perang (Kurosawa, 1993: 239). Salah satu diantaranya berupa video atau film tentang kampanye gemar menabung serta kampanye penggunaan produk dalam negeri.

Video yang berdurasi sekitar tujuh menit dua belas detik ini dibagi menjadi dua sesi.

2 Perusahaan Film Jawa yang dibentuk di bawah pengawasan Sendenbu, dikepalai oleh Oya Sōichi, seorang kritikus Jepang yang terkenal yang bekerja sebagai staf Sendenbu. 
Sesi pertama, Jepang mencoba untuk menarik minat masyarakat dalam mempercayakan uang mereka kepada institusi pemerintah, dalam hal ini adalah menabung melalui kantor pos. Di sesi berikutnya, Jepang mencoba untuk menanamkan kepada masyarakat tentang rasa cinta terhadap produk-produk dalam negeri serta mencoba mengambarkan tentang perubahan-perubahan yang sudah dilakukan oleh Jepang di Jawa seperti dalam bidang kesehatan dan transportasi.

Dalam menarik minat masyarakat untuk menabung di kantor pos, Jepang memberikan gambaran bahwa saat itu Indonesia seolaholah telah lepas dari cengkraman imperialisme Barat dan bahwa dalam memperjuangkan kemerdekaan dan kebebasan Asia, seluruh rakyat harus berpartisipasi salah satunya adalah dengan jalan berperilaku hemat dan menabungkan uangnya sedikit demi sedikit bagi penghidupan yang layak di kemudian hari. Salah satu narasinya juga menyampaikan tentang tata-cara menabung di kantor pos. Yang menarik bahwa untuk benar-benar membentuk logika di mana menyimpan uang dengan cara ditabungkan di kantor pos adalah merupakan tindakan yang tepat, video ini diberikan ilustrasi bahwa dengan tidak menyimpan uang di rumah, uang lebih aman dari pencurian. Selain itu, ada ilustrasi juga yang mengambarkan bahwa dengan menabungkan uang sedikit demi sedikit, seorang tukang becak mampu membeli becaknya dan kemudian bisa tersenyum dengan cerah. Selain itu, hal yang perlu dicatat adalah bahwa ilustrasi-ilusitrasi dalam video ini memanfaatkan karikatur yang menarik guna memudahkan masyarakat memahami dan mengingat pesan yang ingin disampaikan. ${ }^{3}$

3 Video diunduh di http://www.youtube.com/ watch?v=cYpLQRwuQM8 28 Maret 2012 pukul 24:11 WIB. Berdasarkan informasi yang tercantum di tautan tersebut, video ini diambil dari DVD dokumenter "De Japanse Overheersing” yang dirilis oleh NIOD, berisi 13 video koleksi propaganda zaman pendudukan Jepang di Indonesia.

\section{Radio}

Radio juga menjadi salah satu alat propaganda yang intensif yang dimanfaatkan pemerintah pendudukan Jepang dalam menjangkau berbagai kalangan masyarakat. Bahkan anjuran untuk memperdengarkan siaran radio di dalam penjara pun juga dilakukan. Seperti yang ditulis dalam harian Asia Raya sebagai berikut,

“... soepaja didalam pendjara diadakan radio boeat orang-orang jang kena hoekoem, soepaja mereka itoe dapat poela mendengarkan siaran jg. Berfaedah (Asia Raya, 1943: 1).”

Stasiun pemancar radio yang dikuasai dan dikontrol penuh oleh pemerintah di bentuk pada tanggal 1 Oktober 1942 dengan nama Jawa Hoso Kanriyoku (Biro Pengawasan Siaran Jawa) di bawah Sendenbu. Jawa Hoso Kanriyoku memiliki delapan stasiun pemancar lokal yang tersebar di berbagai daerah meliputi Jakarta, Bandung, Yogyakarta, Surakarta, Banyumas, Semarang, Surabaya dan Malang (Kurosawa, 1993: 255).

Berbagai tema siaran diperdengarkan setiap hari melalui stasiun-stasiun pemancar tersebut, mulai dari berita dalam bahasa Jawa, Sunda, Indonesia maupun Jepang, hingga pengumuman pemerintah dan musik serta ceramah keagamaan. Berkenaan dengan propaganda menabung, seruan-seruan agar berhemat dan menabung juga disuarakan melalui pemancar radio. Kemudian, dalam rangka lomba penciptaan lagu bertema menabung, tentang syarat-syarat dan hasil lomba diumumkan juga melalui radio. Lagu yang kemudian terpilih dalam lomba tersebut juga diperdengarkan secara rutin dalam siaran-siaran radio (Asia Raya, 1945). Sehingga jelas bahwa radio juga merupakan salah satu alat propaganda Jepang dalam menyerukan semangat menabung di kalangan masyarakat Indonesia pada masa itu. 


\section{Kesenian dan Sastra: Upaya Menyentuh Hati Rakyat}

Kesenian dan sastra dijadikan sebagai salah satu alat propaganda karena dapat menggelorakan perasaan orang banyak. Disamping itu, melalui kesenian dan sastra, misi-misi propaganda dapat dititipkan dengan cara yang lebih halus. Oleh karena itu pemerintah Jepang menfokuskan kesenian sebagai bagian penting dari unsur pendukung perang.

\section{Nyanyian atau Lagu}

Nyanyian atau lagu merupakan sarana propaganda Jepang yang lain yang dimanfaatkan untuk menyampaikan gagasangagasan serta menyulut moral dan semangat perang di kalangan masyarakat. Ada dua jenis lagu yang sering diajarkan dan diperdengarkan semasa masa pendudukan. Pertama adalah lagu-lagu berbahasa Jepang yang berasal langsung dari Jepang, dan berikutnya adalah lagu-lagu propaganda dalam bahasa Indonesia (Kurosawa, 1993: 253). Lagu-lagu berbahasa Indonesia yang dimaksud tersebut adalah lagu gubahan dari bahasa Jepang maupun lagu yang memang diciptakan di Indonesia. Salah satu lagu yang diciptakan dalam bahasa Indonesia adalah lagu yang berjudul "Menaboeng", sebuah lagu yang diciptakan dalam rangka mensukseskan gerakan gemar menabung yang dilancarkan Jepang saat itu. Lirik lagu tersebut mengobarkan bahwa dengan menabung, baik tua maupun muda juga telah ikut berperang di garis belakang. Selain itu, lirik tersebut juga mengajarkan bahwa dengan rajin menabung dan berhemat, maka di masa tua akan sejahtera dan kaya raya (Djawa Baroe, 1945: 34). Melalui lirik lagu tersebut pula, jelas bahwa semangat menabung uang diibaratkan juga dengan semangat mengangkat senjata di medan perang.

Lagu sebagai bagian dari karya seni yang dimanfaatkan dengan baik sebagai sarana propaganda menabung, bisa dilihat juga dari adanya perlombaan penciptaan lagu bertemakan menabung uang yang diselengarakan oleh pemerintah pendudukan. Perlombaan tersebut bertemakan "Njanjian menaboeng oeang" dengan syarat-syarat umum merupakan lagu berbahasa Indonesia dengan melodi dan lirik yang segar dan riang serta mudah dipahami banyak orang. Pemerintah menyiapkan total hadiah senilai f 900 untuk tiga pemenang utama dan lima pemenang hiburan. Selain mendapatkan hadiah uang, lagu yang berhasil menjadi juara akan diumumkan dan diperdengarkan di seluruh pulau Jawa melalui radio (Asia Raya, 1945: 25).

\section{Sandiwara dan Kamishibai}

Perhatian yang cukup besar pada seni pertunjukan, diwujudkan dengan membentuk berbagai organisasi dalam rangka mengawasi dan meningkatkan kegiatan sandiwara. Berkaitan dengan propaganda menabung, pemerintah melalui Sendenbu mengirimkan sandiwara keliling ke seluruh Jawa untuk menyebarkan semangat menabung di kalangan masyarakat. Sandiwara keliling tersebut dipercayakan kepada empat grup sandiwara atas prakarsa dari Djawa Eiga Kosha. Setiap grup sandiwara tersebut bermain di tujuh tempat berbeda setiap kali mengunjungi satu kota. Dalam hal ini, sandiwara yang mereka mainkan mengusung tema tentang betapa pentingnya kegiatan menabung dilakukan oleh masing-masing orang (Asia Raya, 1945: 36).

Seni panggung lain yang juga digunakan Jepang sebagai media propaganda adalah kamishibai yang berarti teater kertas. Kamishibai merupakan sebuah hiburan pop di kalangan masyarakat Jepang masa itu yang konsep pertunjukannya adalah menyajikan serangkaian gambar di atas kertas karton sambil bercerita. Rangkaian gambar kamibashi ini tidak dicetak melainkan dilukis dengan tangan satu per satu. Masing-masing lukisan berukuran sekitar satu meter persegi (Kurosawa, 1993: 250). 
Di Indonesia khususnya di Jawa, produksi sekaligus pertunjukan kamibashi saat itu berada di bawah pengawasan Sendenbu. Bermacam-macam tema diproduksi dan banyak di antaranya merupakan kisahkisah bertemakan semangat menabung dan promosi tabungan pos. Setidaknya ada tiga buah pertunjukan kamishibai yang mengangkat tema tentang semangat berhemat dan menabung. Di antaranya adalah "Nasehat Jang Bermanfa'at", "Insaf Membawa Bahagia", "Menoedjoe Kemenangan Dengan Giat Menaboeng" (Kurosawa, 1993: 112). Ketiga tema tersebut kemudian juga dimuat di beberapa edisi majalah Djawa Baroe sebagai cerita bergambar. Cerita bergambar tersebut mengandung pesan moral supaya berhemat dan hidup sederhana serta menekankan betapa pentingnya menabung untuk kepentingan masa depan.

\section{Cerpen}

Bidang sastra, Jepang banyak memanfaatkan cerpen dan cerita bergambar untuk menyebarkan semangat menabung terutama bagi pembaca majalah dan surat kabar. Produksi cerpen, cerita bergambar dan bahkan puisi tidak hanya dilakukan oleh pemerintah dan propagandis. Jepang juga melibatkan masyarakat umum melalui perlombaan mengarang bertema menabung. Salah satu lomba tersebut dilaksanakan di Puwokerto dan dimenangkan oleh Johan Anwar dengan judul karangannya "Menoejoe Kemenangan Dengan Giat Menaboeng". Kriteria penilaian lomba diterangkan bahwa karangan harus mengandung unsur ajakan kepada masyarakat umum dan memberikan penjelasan supaya rakyat kebanyakan menangkap makna menabung dengan mudah (Djawa Baroe, 1944: 27).

Cerita yang dimenangkan oleh Johan Anwar tersebut, memuat poin-poin yang membicarakan tentang keutamaan menabung sebagai jalan meraih kemenangan perang. Selanjutnya dijelaskan pula bahwa untuk menabung uang paling aman adalah di kantor pos bukan di rumah. Penekanan utamanya adalah bahwa menyimpan uang di rumah mengundang bahaya, sedangkan menyimpan uang di kantor pos justru mendapatkan bunga. Selanjutnya dia menguraikan dengan disertai gambar tentang keuataman-keutamaan menabung uang di kantor pos tersebut lebih detail dengan kasus-kasus yang bisa terjadi akibat menyimpan uang di rumah dan di kantor pos. Penggambaran oleh Johan Anwar tersebut diantaranya adalah apabila terjadi kebakaran dan perampokan, menyimpan uang di rumah merupakan kesalahan besar, sebaliknya dengan menyimpan tabungan di kantor pos, selain mendapatkan keamanan dan keuntungan bunga, masyarakat juga diberi kesempatan untuk ikut membangun negara (Djawa Baroe, 1944: 28-32).

Contoh lain adalah sebuah cerpen yang juga dimuat di harian Asia Raya yang mengangkat tema mengenai keutamaan menyimpan uang, ditulis oleh S.Ozoe. Cerpen tersebut berkisah tentang seorang prajurit yang gemar menyimpan uang. Dengan uang simpanannya itu dia mampu membantu orang-orang di sekitarnya yang mendadak membutuhkan bantuan dengan segera (Asia Raya, 1943: 2).

\section{Sekolah dan Kantor Pemerintahan: Antara Kewajiban dan Kerelaan}

Selain memanfaatkan media massa dan kesenian, pemerintah pendudukan dengan rencana yang sistematis melalui instansiinstansi pemerintah maupun swasta, baik instansi formal maupun informal juga mengajak, menyerukan dan memerintahkan masyarakat supaya menyisihkan uangnya ditabung di lembaga keuangan. Kegiatan menabung digalakkan terutama di sekolahsekolah dan kantor-kantor pemerintahan di berbagai daerah. 
Siswa, Otoritas Sekolah dan Kewajiban Menabung

Sudah bukan hal baru lagi bahwa pendidikan merupakan salah satu poin terpenting dari upaya suatu kelompok untuk menanamkan benih-benih propaganda. Hal ini juga berlaku untuk pendidikan di wilayah pendudukan Jepang masa itu. Melalui sekolah-sekolah, ajaran yang berkaitan dengan semangat perang dan visi misi meraih kejayaan sebagai bangsa Asia ditanamkan setiap hari. Telah dijelaskan sebelumnya bahwa seruan menabung adalah salah satu bagian dari propaganda perang Jepang tersebut, dan sekolah sebagai lembaga pendidikan formal menjadi salah satu sarana yang dimanfaatkan untuk mensukseskannya.

Berkaitan dengan penanaman semangat menabung di lingkungan sekolah, harian Asia Raya pada tanggal 11 Mei 1943 memberitakan bahwa Majelis Guru Taman siswa telah mengeluarkan peraturan untuk mewajibkan anak-anak sekolah agar menabungkan sebagian dari uang sakunya, kira-kira sejumlah 50 sen setiap bulan setiap anak. Setelah terkumpul, uang tabungan tersebut kemudian dibawah koordinasi sekolah akan disimpan di kantor pos (Asia Raya, 1943: 2). Sehingga, bisa dikatakan bahwa kegiatan menabung menjadi agenda wajib bagi para siswa dan merupakan program resmi yang didukung secara sistematis baik oleh pemerintah maupun oleh otoritas sekolah pada masa itu. Hal ini diperkuat dengan berita Asia Raya masih pada bulan yang sama tanggal 20 Mei 1943, diberitakan bahwa di Jogja semangat menabung dikalangan murid-murid sekolah semakin hari semakin tinggi. Menurut pemeriksaan Kantor Pengawasan Pengajaran, setiap hari masing-masing Sekolah Rakyat Negeri di Jogja, dapat menghimpun $f 30$ (Asia Raya, 1943: 2).

Tidak hanya di Jogjakarta, semangat menabung juga ditularkan kepada para pelajar di Jakarta. Dijelaskan bahwa Sekolah Rakyat di seluruh Jakarta setiap sore melakukan sosialisasi pentingnya menabung kepada siswa- siswanya dibantu oleh petugas dari Chokin Kyoku(Tabungan Pos). Mereka melakukan pidato-pidato dan pertunjukan kamishibai untuk menanamkan budaya berhemat dan menabung di kalangan anak-anak sekolah tersebut. Dinyatakan pula bahwa kegiatan semacam ini akan dilakukan secara rutin dan teratur di setiap pelosok Jakarta (Asia Raya, 1944). Selain program semacam itu, pemerintah juga menyelengarakan suatu kegiatan khusus yang disebut "pekan menaboeng" bagi anakanak di Jakarta. Kegiatan tersebut diadakan di sekolah-sekolah dengan konsep penyuluhan tentang manfaat-manfaat menabung serta pengajaran lagu "mari menaboeng" kepada murid-murid (Asia Raya, 1944). Tidak ubahnya di Jogjakarta dan Jakarta, koresponden Asia Raya di Semarang juga mengabarkan bahwa murid-murid sekolah di wilayah Semarang telah rutin menabungkan uangnya setiap hari Jumat sesuai dengan anjuran pemerintah (Asia Raya, 1943).

\section{Kantor-Kantor Pemerintahan dan Sosialisasi Gerakan Menabung}

Anjuran untuk menabung telah dilakukan bagi pegawai pemerintah di seluruh wilayah Keraton Solo secara hierarki. Mulai dari pangkat terendah diharuskan menabung 25 sen, hingga pangkat yang tertinggi (Para Kecho) diharuskan menabung 20 rupiah tiap bulannya, dan uang tabungan tersebut disimpan di Kantor Pos (Asia Raya, 1943: 2).

Selanjutnya, di kantor daerah Bogor bahkan diadakan musyawarah khusus untuk membahas tentang program menabung. Peserta musyawarah tersebut mulai dari Kepala Daerah dan perangkatnya hingga wakil-wakil golongan penduduk sampai tingkat tonarigumi. Pertemuan tersebut diawali dengan pidato mengenai pentingnya menabung untuk memperkuat perekonomian rakyat. Selanjutnya diperdengarkan laporanlaporan dari kepala kantor pos dan direkturdirektur bank tentang jumlah uang yang 
telah ditabung oleh penduduk. Setelah itu dimulailah agenda pembahasan rapat tentang cara-cara meningkatkan partisipasi masyarakat dalam program menabung. Akhirnya, diambil beberapa keputusan yang telah disepakati bersama, diantaranya bahwa akan diadakan pemasangan poster-poster ke seluruh penjuru Bogor untuk mengobarkan semangat menabung. Dalam mensukseskan upaya tersebut, akan dibentuk pula komisi khusus untuk memproduksi poster-poster menabung termasuk memilih kata-kata dan gambar yang akan digunakan agar menarik minat rakyat. Selain itu disepakati pula dalam pertemuan tersebut bahwa dalam rangka memantabkan program menabung, maka akan diadakan suatu kegiatan yang diberi nama "Pekan Penaboeangan" di seluruh wilayah Bogor (Asia Raya, 1944: 27).

Selain Bogor, dalam pertemuan bulanan Pangreh-Praja Kabupaten Blora, salah satu agendanya juga mendengarkan pidato tentang betapa pentingnya kegiatan menabung bagi segenap rakyat Indonesia pada umumnya dan masyarakat Blora pada khususnya. Dijelaskan bahwa kegiatan menabung merupakan salah satu ruh dari kesejahteraan perekonomian rakyat karena erat hubungannya dengan kehidupan sehari-hari. Dalam kesempatan tersebut juga dijelaskan tentang tata cara menabung di Chokin Kyoku. Selain itu, ditekankan pada para pejabat Blora tersebut bahwa mereka adalah garda terdepan dalam menyukseskan kegiatan menabung. Sehingga, hendaknya mereka memberikan contoh kepada masyarakat untuk hidup hemat serta rajin menabung (Asia Raya, 1944). Tidak hanya di Blora, kegiatan menabung di kalangan pejabat pemerintah daerah juga dilakukan oeh para Pangreh Praja di Kabupaten Garut. Diberitakan bahwa setiap bulan, dari mulai opas sampai Bupati menabung di kantor pos dengan jumlah tabungan antara 0,25 rupiah hingga paling banyak 2,250 rupiah.
Beberapa instansi pemerintah yang lain juga melakukan penggalakkan kegiatan menabung diantara pegawai-pegawainya. Salah satunya yang terjadi di kantor Hooki Kyoku (Balai Pengadilan atau Perundangundangan) yang saat itu dikepalai oleh Supomo. Di dalam kantor peradilan tersebut dibentuk sebuah perkumpulan penabungan bagi seluruh pegawainya (Asia Raya, 1944: 2). Dari berbagai uraian tentang program-program yang dilakukan di berbagai kantor pemerintahan di berbagai daerah tersebut, bisa dikatakan bahwa dalam upaya menjalankan propaganda menabungnya, Jepang memanfaatkan organisasi pemerintahannya secara hierarki dari tingkat atas hingga paling bawah.

\section{Penutup}

Gerakan menabung merupakan salah satu program propaganda yang dilancarkan oleh pemerintah pendudukan Jepang. Dengan jeli Jepang memahami bahwa untuk mengerakkan minat masyarakat dalam menyisihkan sebagian pendapatannya dan disimpan di lembaga keuangan resmi memerlukan sebuah upaya yang tidak mudah. Untuk itu, propaganda dalam mensukseskan gerakan menabung ini secara sistematis dilaksanakan mengunakan berbagai perangkat. Demi menjangkau masyarakat semua kalangan, mulai dari pemanfaatan media massa seperti koran, majalah, film dan radio serta kesenian semacam sandiwara dan nyanyian, hingga pengerahan melalui lembaga-lembaga formal dan informal seperti sekolah-sekolah, kantorkantor pemerintah dan himpunan-himpunan masyarakat dilakukan oleh pemerintah pendudukan. 


\section{Daftar Pustaka}

\section{Buku:}

Arifin Bey,. Pendudukan Jepang di Indonesia Suatu Ungkapan Berdasarkan Dokumentasi Pemerintahan Belanda. Jakarta: Kesaint Blanc, 1987

Arsip Nasional Republik Indonesia (Penerbitan Sejarah Lisan). Di Bawah Pendudukan Jepang, Jakarta, 1988

Benda J. Harry, Irikura K. James and Kishi Koichi. Japanese Military Administration in Indonesia: Selected Document (New Heaven: Yale University, 1965

Dick, Howard. Japan's Economic Expantion in The Nederland Indies between the First and Second World Wars. Cambridge University Press, 1989

M.C., Ricklefts.Sejarah Indonesia Modern 12002004. Jakarta: Serambi Ilmu Semesta, 2008

Mohammad Hatta,. Bank Dalam Masjarakat Indonesia. Neira: Fort De Kock, 1942

Kurosawa, Aiko. Mobilisasi dan Kontrol: Studi Tentang Perubahan Sosial di Pedesaan Jawa 1942-1945. Jakarta: PT Gramedia, 1993

Kurosawa,Aiko (1987), Propaganda Media On Java Under Japanese 1942-1945, New York: Southeast Asia Program Publications at Cornell University, 44, 59-128

Kusher, Barak. The Thought War: Japanese Imperial Propaganda, Hawai: University of Hawai'i Press, 2006

Pandu Suharto,. Sejarah Pendirian Bank Perkreditan Rakyat. Jakarta: Lembaga Pengembangan Perbankan Indonesia, 1988

Rahardjo, Damawan. Bank Indonesia Dalam Kilasan Sejarah Bangsa. Jakarta: LP3ES, 1995

Sunaryo. Mengenal Propaganda. Yogyakarta: Liberty, 1982

\section{Majalah:}

"Insaf Membawa Bahagia". Djawa Baroe 15 Juli.1944: 33-34

,"Mari Kita Menaboeng Oeang! Semangat menaboeng di Djawa”. Djawa Baroe Juni.1943: 16-17

"Menoejoe Kemenangan Dengan Giat Menaboeng". Djawa Baroe 1 Oktober. 1944: 27-32

"Nasehat Jang Bermanfa'at". Djawa Baroe 1 Juli.1944: 33-34

"Taboengan Oeang Tonari Gumi".

Djawa Baroe 1 Agustus 1944

\section{Surat Kabar:}

"Banjaknja Penaboeng Dalam Kediri-Joebinjokoe”. Asia Raya 9 September 1943: 2 “Menaboeng”. Asia Raya 25 Februari. "Moerid-Moerid Haroes Menaboeng". Asia Raya 11 Mei. 1943: 2

"Penaboengan Pemoeda". Asia Raya 17 April. 1943: 2

"Penaboeangan Di Bogor Shuu". Asia

Raya 30 Januari. 1945

"Penerangan Tentang Menaboeng." Asia Raya 28 Juli 1943: 2

"Pertoenjoekan Barang-Barang Pentjiptaan Baroe Jang Sesoeai Dengan Keperloean Penghidoepan Dalam Masa Peperangan". Asia Raya. 1945

"Simpanan Oeang Oentoek Waktoe Tertentoe Disertai Hadian Oendian”. Asia Raya 27 Februari 1945

"Taboengan Oeang 2605/2606 di Djawa Haroes Mentjapai f350.000.000.--”. Asia Raya 24 April. 1945 
, "Tentang Menaboeng Oeang Pendapatan Kapas”. Asia Raya 2 Juli 1943: 4

"Oesaha Memperkokoh Perekonomian dan Penaboengan Rakjat”. Asia Raya 10 Februari. 1945

, "Oeang Taboengan Pendoedoek Jawa”. Sinar Matahari 4 Februari, 1944 "Lagi Jalan Penghematan". Tjahaya 12 Juni. 1943

“Taboengan di 17 KU”. Tjahaja 15 Juni. 1943

\section{Video :}

"De Japanse Overheersing : Nederlands-Indie in de Tweede Wereldoorlog".http://www.youtube. com/watch?v=cYpLQRwuQM8diunduh 28 Maret 2012 pukul 24:11 WIB.

\section{Internet:}

Eka Oktavia. Sejarah PT. Bank Tabungan Negara, www.bergfiles.com/i/bf4855faa6h32i0, May 3 2012, 13:05 pm 
